\title{
EFEKTIFITAS BEBERAPA JENIS ATRAKTAN DALAM MENANGKAP TELUR NYAMUK Aedes $S p$ DI KELURAHAN TELUK KECAMATAN PURWOKERTO SELATAN KABUPATEN BANYUMAS TAHUN 2016
}

\author{
Ratna Pramurditya ${ }^{1)}$, Aris Santjaka ${ }^{2)}$, Arif Widyanto ${ }^{3)}$ \\ Jurusan Kesehatan Lingkungan Politeknik Kesehatan Kemenkes Semarang, \\ Jl. Raya Baturaden KM 12 Purwokerto, Indonesia
}

\begin{abstract}
Abstrak
Pengendalian Aedes sp tanpa insektisida dapat digunakan dengan perangkap telur (Ovitrap). Kecamatan Purwokerto Selatan dengan jumlah kasus DBD tertinggi di Kabupaten Banyumas tahun 2015 (92 kasus,1 orang meninggal), Kelurahan yang tinggi kasus DBD yaitu Kelurahan Teluk dengan 22 kasus DBD. Penelitian ini menjawab jenis atraktan dan jenis bahan ovitrap mana yang paling baik untuk menarik nyamuk. Jenis penelitian ini yaitu eksperimen semu (Quasi Experiment) rancangan postest dengan kelompok kontrol (non randomized postest only control group design). Sampel penelitian ini digunakan kriteria inklusi yaitu rumah penderita (3 rumah) dengan rumah disekitar rumah penderita dalam radius 200m yaitu 27 rumah (1 rumah diberi 3 perlakuan ovitrap). Analisis univariat (perhitungan jumlah telur nyamuk pada ovistrip) dan analisis bivariat (uji ANOVA Faktorial). Jumlah telur nyamuk yang paling banyak pada jenis atraktan air rendaman jerami (1.933 butir) dan jenis bahan ovitrap gelas plastik (1436 butir). Spesies nyamuk yang ditemukan Aedes aegypti dan Aedes albopictus. Hasil analisis anova faktorial jenis atraktan 0,00 (p) <0,05 ( $\alpha$ ), significant Ho ditolak jadi ada perbedaan jumlah telur Aedes sp yang terperangkap pada masing-masing jenis atraktan (air rendaman jerami, air rendaman gula dan air setempat). Jenis bahan ovitrap 0,187 (p) >0,05 ( $\alpha$ ), Ho diterima jadi tidak ada perbedaan antara jumlah telur nyamuk dengan jenis bahan ovitrap (tempurung, gelas plastik dan kaleng). Interaksi jenis atraktan dan jenis bahan ovitrap 0,155 (p) >0,05 ( $\alpha$ ), Ho diterima, tidak ada perbedaan interaksi jenis atraktan dan jenis bahan ovitrap. Atraktan dengan air rendaman jerami 20\% paling baik digunakan untuk tempat bertelur nyamuk, sedangkan untuk jenis ovitrap gelas plastik dengan atraktan air rendaman jerami paling baik digunakan. Penggunaan atraktan air rendaman jerami $20 \%$ dengan ovitrap gelas plastik dalam menangkap telur nyamuk dapat diterapkan pada masyarakat.
\end{abstract}

Kata kunci $\quad$ : Telur nyamuk, atraktan, bahan ovitrap

\begin{abstract}
Control of Aedes sp without insecticides can be used to the egg trap (ovitrap). South Purwokerto subdistrict with the highest dengue cases in Banyumas on 2015 (92 cases, 1 death) Teluk is one of the village with 22 cases DBD. This research answer which one the best type of attractant ovitrap and the ovitrap materials for attract mosquitoes. This research is Quasi Experiment (eksperimen semu) posttest design with a control group (nonrandomized posttest only control group design). This research sample used inclusion criteria patient houses (3 houses) with houses around the house of patient in a radius of 200m as many as 27 houses (one house was give 3 treatment ovitrap). Univariate analysis of the results of the calculation the number of mosquito eggs in ovistrip and bivariate analysis used factorial ANOVA test. The number of mosquito eggs most on the type of attractant straw water immersion with 1.933 eggs and ovitrap with plastic cups matelials amout 1.436 eggs. Species of mosquito was found is Aedes aegypti and Aedes albopictus. The results of a factorial ANOVA analysis of the type of attractant $0.00(p)<0.05(\alpha)$, Ho rejected so there are significant differences in the number of eggs of Aedes sp which trapped on each type of attractant (straw water immersion, sugar water immersion and local water), type of material ovitrap $0.187(p)>0.05(\alpha)$, Ho accepted so there are no difference between the number of mosquito eggs with ovitrap material types (shell, plastic glass and cans). Interaction types of attractants and type of material ovitrap $0.155(p)>0.05(\alpha)$, Ho is accepted, there is no difference in the interaction attractant type and types of materials ovitrap. Attractant with the soaking water straw $20 \%$ is best used for mosquito breeding ground, while for the type of attractant ovitrap plastic cups with water soaking hay is best used. The use of attractants water immersion straw ovitrap $20 \%$ with plastic cups in catching the mosquito eggs can be applied to public
\end{abstract}

Keywords $\quad$ : Egg mosquito, attractants, ovitrap materials

\section{PENDAHULUAN}

Rencana Pembangunan Jangka Panjang Bidang Kesehatan (RPJP-K) adalah rencana pembangunan

1) Email : ratnapramurditya@yahoo.co.id

2) Email : arissantjaka@gmail.com

3) Email : arifwidyanto74@yahoo.com nasional di bidang kesehatan yang merupakan penjabaran dari RPJPN Tahun 2005-2025, dalam bentuk dasar, visi, misi, arah dan kebutuhan sumber 
daya pembangunan nasional di bidang kesehatan untuk masa 20 tahun ke depan. Berbagai penyakit menular masih merupakan masalah kesehatan masyarakat. Incidence Rate penyakit demam berdarah (DBD) meningkat tahun demi tahun, disebabkan penanganan lingkungan kurang baik yang berkaitan dengan masih kurangnya perilaku hidup bersih dan sehat. (Depkes RI, 2009, h.1 dan 12).

Penyakit DBD disebabkan oleh virus demam dengue dengan tipe DEN 1, DEN 2, DEN 3 dan DEN 4. Virus tersebut termasuk dalam Arthropodborne viruses (arboviruses) dan termasuk kategori atau famili Flaviridae. Virus dengue dapat ditularkan melalui gigitan nyamuk Aedes, terutama Aedes aegypti. (Dantji T. Sembel, 2009, h.60)

Pengendalian nyamuk Aedes aegypti dapat dilakukan terhadap nyamuk dewasa dan pada stadium larva/jentik. Pemberantasan nyamuk dewasa yang umum dilakukan melalui pengasapan/fogging dengan menggunakan insektisida. Fogging saja tidak cukup karena dengan fogging yang mati hanya nyamuk dewasa saja, larva nyamuk tidak mati dengan melakukan pengasapan (Depkes RI, 2012). Selain itu juga pengasapan menggunakan bahan insektisida organofosfat dapat menimbulkan resistensi akibat dosis yang tidak tepat. (Bento dkk, 2003)

Salah satu metode pengendalian Aedes sp tanpa insektisida adalah penggunaan perangkap telur (Ovitrap). Metode ini berhasil menurunkan densitas vektor di beberapa negara adalah penggunaan perangkap telur (ovitrap) berupa peralatan untuk mendeteksi keberadaan nyamuk Aedes sp. Cara ini telah berhasil dilakukan di Singapura dengan memasang 2.000 Ovitrap di daerah endemis DHF (Service, 1996). Ovitrap digunakan untuk mendeteksi manifestasi nyamuk ke area baru yang sebelumnya pernah dibasmi. Alat ini dikembangkan oleh Fay dan Eliason pada tahun 1966 dan disebarluaskan oleh CDC. (Sayono dkk, 2010).

Penggunaan atraktan pada ovitrap terbukti dapat menarik nyamuk untuk meletakkan telurnya seperti air rendaman jerami yang terbukti dapat menarik nyamuk untuk bertelur (Sofiatul Mardiyah, 2014), air gula pasir yang sudah terbukti dapat menarik nyamuk untuk meletakan telurnya (Arif Widyanto, 2015), dan air setempat (control).

Jenis bahan ovitrap yang dapat digunakan dapat dari berbagai macam, seperti dari hasil penelitian Taufiq Hidayat, 2007 nyamuk lebih menyukai ovitrap alami yaitu tempurung kelapa dari pada ovitrap buatan seperti gelas kaca, menurut Dirjen PPM dan PLP Depkes RI (1992,h.10), ovitrap dapat berupa kaleng (bekas kaleng susu atau gelas plastik )

Kejadian DBD di Kabupaten Banyumas masih dapat ditemukan, berdasarkan data Dinas Kesehatan Kabupaten Banyumas dari tahun 2010-2015 masih ditemukan kasus DBD. Angka kejadian DBD pada tahun 2010 yaitu 696 kasus (7 orang meninggal) dengan IR 42,6/100.000 dan CFR 1,01\%. Tahun 2011 sebanyak 201 kasus (3 orang meninggal) dengan IR 12,31/100.000 dan CFR 1,49 \%. Tahun 2012 mengalami penurunan tercatat 200 kasus (4 orang meninggal) dengan IR 11,78/100.000 dan CFR 2,01\%. Tahun 2013 kasus mengalami kenaikan tercatat 543 kasus (4 orang meninggal) dengan IR 32,14/100.000 dan CFR 0,74\%. Tahun 2014, kasus DBD mengalami penurunan yaitu 209 kasus (4 orang meninggal) dengan IR 12,89/100.000 dan CFR 1,91\%. Kasus DBD mengalami peningkatan kembali pada tahun 2015 yaitu 231 kasus (1 orang meninggal) sampai bulan Oktober 2015 dengan IR 14,14/ 100.000 dan CFR 0,43 \%. (Data Kasus DBD Dinas Kesehatan Kabupaten Banyumas)

Wilayah Kecamatan di Kabupaten Banyumas dengan jumlah kasus DBD tertinggi tahun 2015 adalah Kecamatan Purwokerto Selatan yaitu sebanyak 92 kasus dengan 1 orang meninggal dunia. Berdasarkan data Puskesmas Purwokerto Selatan kasus DBD tahun 2010-2015 masih ditemukan. Tahun 2010 sebanyak 126 kasus. Angka kejadian kasus mengalami penurunan pada tahun 2011 sebanyak 67 kasus, kemudian turun menjadi 31 kasus pada tahun 2012. Kasus DBD mengalami kenaikan pada tahun 2013 sebanyak 92 kasus dan menurun pada tahun 2014 yaitu 67 kasus. Kasus DBD mengalami kenaikan pada tahun 2015 yaitu 92 kasus dengan 1 orang meninggal dunia. Wilayah yang tinggi kasus DBD adalah Kelurahan Teluk dengan 22 kasus DBD. (Data Puskesmas Purwokerto Selatan Tahun 2015)

\section{BAHAN DAN METODE}

Jenis penelitian ini adalah eksperimen semu (Quasi Experiment) dengan rancangan postest dengan kelompok kontrol (non randomized postest only control group design). Rancangan ini pengelompokan anggota sampel pada eksperimen dari kelompok kontrol tidak dilakukan secara random atau acak.

Replikasi pada penelitian ini dapat dihitung dengan rumus Federer (1963) (Supranto, J. 2000) sebagai berikut:

$$
\begin{aligned}
&(t-1)(r-1) \geq 15 \\
&(9-1)(r-1) \geq 15 \\
& 8 r-8 \geq 15 \\
& 8 r \geq 23 \\
& r \geq 2,875
\end{aligned}
$$

Dibulatkan menjadi 3

Keterangan:

$$
\mathrm{t}=\text { Jumlah perlakuan, }
$$$$
\mathrm{r}=\text { Jumlah replikasi }
$$

Pengulangan yang dilakukan pada masingmasing perlakuan adalah 3 kali replikasi dan jumlah perlakuan adalah 9. Jumlah obyek yang diteliti sebanyak 27 perlakuan.

Pembuatan atraktan air rendaman jerami dengan cara 200 gram jerami direndam dengan 1 liter air dan 
didiamkan selama seminggu, sehingga menghasilkan atraktan air rendaman jerami 20\%. Pembuatan air rendaman dula dengan cara 200 gram gula pasir direndam dengan 1 liter air dan didiamkan selam seminggu, maka akan menghasilkan atraktan air rendaman gula 20\%. Air setempat yang ada dilokasi yaitu air sumur gali yang digunakan sebagai kontrol. Bahan ovitrap digunakan tempurung kelapa, kaleng yang dicat hitam dan gelas plastik yang dicat hitam.

Analisis yang digunakan yaitu analisis univariat yang dilakukan terhadap tiap veriabel dari penelitian, pada analisis univariat data yang diperoleh dari hasil perhitungan jumlah telur nyamuk pada ovistrip dan nalisis bivariat yaitu data yang dikumpulkan diolah menggunakan uji ANOVA Faktorial karena percobaan dilakukan lebih dari satu yaitu jenis atraktan dan jenis bahan ovitrap, serta adanya replikasi. (Aris Santjaka, 2011, h.11)

\section{HASIL DAN PEMBAHASAN}

\section{Deskripsi Lokasi}

Lokasi penelitian berada di RT 05 dan 09 RW 03 Kelurahan Teluk, dengan jumlah penderita DBD yaitu 3 orang. Jarak antar rumah responden (27 responden) sangat berdekatan. Kondisi lokasi penelitian sangat mendukung nyamuk dapat berkembang biak, terdapat lahan yang banyak pohon bambu yang mengelilingi lokasi dan terdapat sungai disekitar lokasi. Kondisi rumah juga dapat mendukung, seperti tidak menggunakan kawat kasa pada lubang ventilasi dan pintu rumah yang terbuka karena mayoritas warganya adalah pedagang seperti mebuka warung sehingga pintu selalu terbuka.

\section{Kondisi Lingkungan Fisik}

Suhu, kelembaban, dan pencahayaan diukur pada tempat pemasangan ovitrap di dalam rumah yang berada di RT 5 dan RT 9 RW 3 Kelurahan Teluk, Kecamatan Purwokerto Selatan dilakukan selama 2 Minggu. Pengukuran dilakukan pada 27 rumah secara serentak mulai pukul 08.00 WIBselesai, dengan jumlah pengukur 6 orang yang dibagi 3 tim (1 tim = 2 orang).

1. Kelembaban

Terjadi kecenderungan kelembaban naik sampai hari ke 13 dan turun pada hari ke 14 dengan rata-rata kelembaban selama 14 hari yaitu 85\%, kelembaban maximum (tertinggi) 90\% dan kelembaban minimum (terendah) 77\%, sebagaimana dapat dilihat pada gambar 3.1

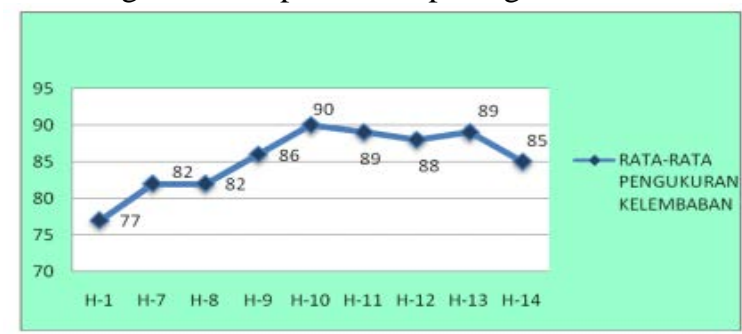

Gambar 3.1. Grafik Pengukuran Kelembaban di RT 05 dan RT 09, RW 03 Kelurahan Teluk Kecamatan Purwokerto Selatan

Kelembaban pada lokasi penelitian selama 2 minggu pengamatan diperoleh hasil 77\%90\%. Hasil kelembaban di lokasi penelitian mendukung nyamuk untuk dapat hidup karena kelembaban nisbi pada nyamuk antara 75\%93\%, sehingga kondisi ini membuat nyamuk dapat hidup dan berkembang biak di lokasi tersebut.

Kelembaban udara adalah banyaknya kandungan uap air dalam udara yang biasanya dinyatakan dalam persen (\%). Jika dalam udara ada kekurangan air yang besar, maka udara ini mempunyai daya penguapan yang besar. Sistem pernafasan pada nyamuk adalah menggunakan spiracle. Adanya spiracle yang terbuka tanpa ada mekanisme pengaturannya, pada waktu kelembaban rendah akan menyebabkan penguapan air dari dalam tubuh nyamuk yang dapat mengakibatkan keringnya cairan tubuh nyamuk. Salah satu musuh nyamuk adalah penguapan. Pada kelembaban kurang dari 60\% umur nyamuk akan menjadi pendek sehingga tidak cukup untuk siklus pertumbuhan parasit di dalam tubuh nyamuk. (Ditjend PPM \& PL, 2004, h.9)

Nyamuk merupakan hewan berdarah dingin dimana serangga pernafasannya menggunakan sistem trakhea, spiracle sebagai tempat keluar masuknya udara, spiracle terbuka jika serangga terbang atau beraktifitas, hal ini disebabkan nyamuk membutuhkan oksigen lebih banyak saat terbang, dampaknya penguapan cairan dalam tubuh nyamuk akan lebih besar dengan demikian cara nyamuk beradaptasi adalah dengan mengurangi jarak terbang, sedangkan waktu istirahat spiracle tertutup. Sistem ini dimaksudkan untuk mempertahankan kelembaban tubuh nyamuk dari penguapan sehingga tidak mudah mengalami dehidrasi, karena nyamuk sangat tergantung pada kelembaban lingkungannya. (Aris Santjaka, 2013, h.62)

\section{Pencahayaan}

Perumusan kecenderungan pencahayaan mengalami penurunan dari pengamatan hari ke 1 sampai hari ke 14 dimulai dari 27 lux sampai yang terendah 8 lux pada hari ke 13 dengan rata-rata pencahahayaan selama 14 hari yaitu 18 lux, sebagaimana dapai dilihat pada gambar 3.2. 


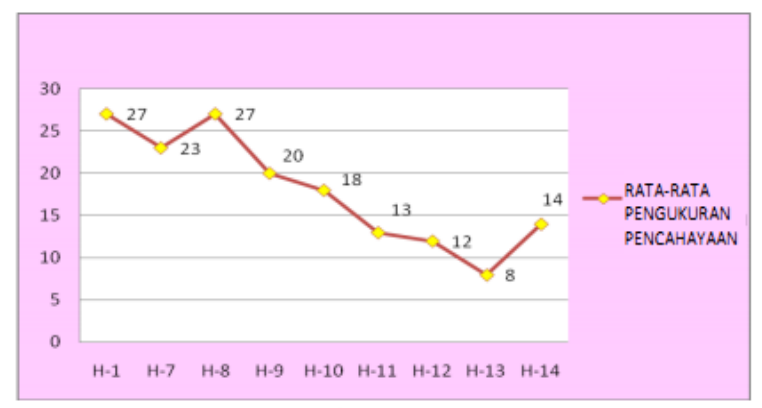

Gambar 3.2. Grafik Rata-Rata Pengukuran

Pencahayaan di RT 05 dan RT 09, RW 03 Kelurahan Teluk Kecamatan Purwokerto Selatan

Cahaya merupakan energi dalam bentuk gelombang elektromagnetik yang berpindah dengan cara radiasi, sedangkan radiasi adalah proses perpindahan panas melalui gelombang elektromagnet atau peket-paket energi (foton) yang dapat menyebar sampai jarak yang sangat jauh tanpa harus memerlukan interaksi dengan medium (Koestoer, 2002 p.183, dalam Aris Santjaka, 2013, h.51). Radiasi matahari terjadi secara terus menerus, hal ini menimbulkan panas sebagai dampak adanya pergesekan gas di atmosphere, seperti hukum thermodinamika kesatu, yang menyatakan enersi dipancarkan sebanding dengan panas yang ditimbulkan medium (Koestoer, 2002 p.107, dalam Aris Santjaka, 2013, h.53), dengan demikian semakin panas suhu ambient akan semakin cepat pergerakan udara.

Hasil penelitian menunjukkan pencahayaan di tempat peletakan ovitrap cenderung gelap yaitu 8-27 lux. Pencahayaan berpengaruh terhadap aktivitas dan tempat peletakan telur nyamuk Aedes aegypti. Nyamuk tersebut cenderung menyukai tempat yang teduh, tidak langsung terkena sinar matahari. Intensitas cahaya untuk kehidupan nyamuk adalah <60 lux. (Depkes, 2007). Peletakkan ovitrap juga memepengaruhi kondisi pencahayaan, karena ovitrap diletakkan di sudut dalam rumah yang telindung dari sinar matahari seperti kamar tidur, ruang keluarga, dapur, dekat kamar mandi. Tingkat pencahayaan ini sesuai dengan bionomik nyamuk yang menyukai tempat yang gelap, tidak terkena langsung cahaya matahari.

Nyamuk akan hinggap di tempat-tempat dimana terdapat kondisi yang optimum untuk beristirahat setelah menggigit untuk menunggu pematangan telur, setelah itu nyamuk akan bertelur dan menggigit lagi. Tempat-tempat yang disenangi nyamuk untuk hinggap atau istirahat selama menunggu waktu bertelur adalah tempat-tempat yang gelap, lembab dan sedikit angin (Dirjen PP dan PL, 2007a, h.28).

3. Suhu
Terjadi kecenderungan suhu turun sampai hari ke 10 naik sampai hari ke 14 dengan ratarata suhu selama 14 hari $29^{\circ} \mathrm{C}$, suhu maximum (tertinggi) $31^{\circ} \mathrm{C}$ dan suhu minimum (terendah) $26{ }^{\circ} \mathrm{C}$, sebagaimana dapat dilihat pada gambar 4.2 .

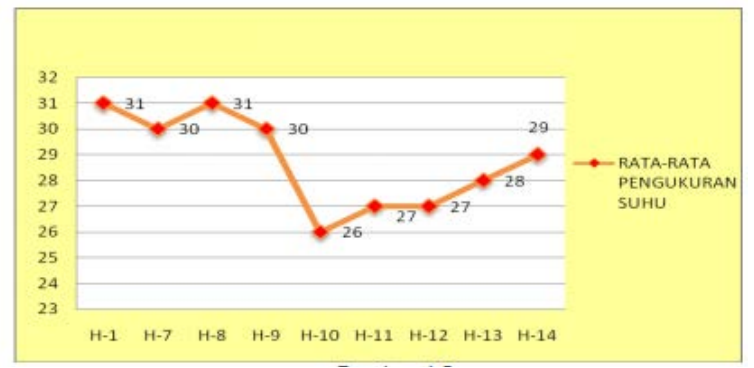

Gambar 4.2. Grafik Pengukuran Suhu di RT 05 dan RT 09, RW 03 Kelurahan Teluk Kecamatan Purwokerto Selatan

Suhu pada tempat pemasangan ovitrap di dalam rumah yang berada di RT 5 dan RT 9 RW 3 Kelurahan Teluk, Kecamatan Purwokerto Selatan dari $26-31^{\circ} \mathrm{C}$, kondisi ini membuat nyamuk dapat hidup. Kondisi cuaca pada lokasi penelitian setiap harinya tidak menentu sehingga hasil pengukuran suhu tidak stabil. Kecepatan perkembangan nyamuk bergantung dari kecepatan proses metabolisme yang sebagian dipengaruhi oleh suhu. Pertumbuhan nyamuk akan berhenti sama sekali apabila suhu kurang dari $10^{\circ} \mathrm{C}$ dan lebih dari $40^{\circ} \mathrm{C}$. Suhu rata-rata optimum untuk perkembangan nyamuk adalah $25^{\circ}-27^{\circ}$ C. (DIT.JEN.PP \& PL, 2007a, h.8)

Suhu di lokasi penelitian suhunya tinggi sedangkan pencahayaannya rendah, hal ini karena ada perpindahan panas atau energi dalam suatu sistem melalui tahap radiasi, konduksi, dan konveksi. Radiasi merupakan transfer enersi panas dari suatu permukaan obyek ke obyek lainnya tanpa mengalami kontak dari kedua obyek. Konduksi merupakan pemaparan energi dari suatu obyek ke obyek lain dengan jalan kontak langsung. Konveksi merupakan perpindahan panas yang disertai perpindahan partikel-partikelnya, sehingga massa udara lebih ringan, lingkungan menjadi panas tanpa bersentuhan langsung. Pengukuran suhu dilakukan di dalam rumah dan menunjukkan suhu tinggi karena terjadi terjadi transfer enersi panas dari matahari ke atap rumah yang merambat ketembok dan lantai sehingga suhu di dalam ruangan menjadi tinggi walaupun cahayanya rendah. (Aris Santjaka, 2013, h. 53)

Suhu udara mempengaruhi perkembangan virus di dalam tubuh nyamuk. Nyamuk Aedes $s p$ dapat bertahan hidup pada suhu rendah tetapi metabolisme menurun bahkan berhenti bila suhunya di bawah suhu kritis. Pada suhu yang lebih tinggi dari $35{ }^{\circ} \mathrm{C}$ juga mengalami 
perubahan dalam arti lebih lambatnya proses fisiologi. Hal ini disebabkan karena terjadi denaturasi protein dalam tubuh nyamuk dan kemungkinan terganggu keseimbangan dalam proses metabolisme dan timbulnya sisa-sisa metabolisme yang beracun di dalam tubuh sehingga akan mengurangi efektivitas nyamuk. (Abdul Syukur, 2012)

Peran suhu yang cukup besar terkait pada sistem pernafasan dari nyamuk. Sistem pernafasan nyamuk menggunakan sistem trachea yaitu alat pernafasan yang dimiliki oleh nyamuk yang bermuara pada spiracle yaitu lubang kecil berdiameter kurang dari $1 \mathrm{~mm}$ terletak di kerangka luar (eksoskeleton) terletak secara berpasangan pada setiap segmen tubuh, spiracle ini mempunyai katup yang dikontrol oleh otot sehingga membuka dan menutup secara teratur. Spiracle ini akan tertutup saat nyamuk sedang istirahat dan terbuka sesaat jika dibutuhkan, namun jika nyamuk terbang spiracle ini terbuka. Tertutupnya spiracle saat istirahat agar nyamuk tidak kekurangan banyak cairan, karena nyamuk tidak mempunyai regulator untuk mempertahankan kelembaban tubuhnya. (Depkes RI, 2007 dalam Aris Santjaka, 2013, h. 58)

\section{Jumlah Telur Didasarkan Pada Jenis Atraktan}

Pemasangan ovitrap menggunakan tiga jenis atraktan yaitu air rendaman jerami, air rendaman gula pasir dan air setempat yang ada di lokasi penelitian yaitu air sumur gali. Jumlah telur nyamuk yang di dapat dari ketiga jenis atraktan ini yaitu sebagai berikut:

Tabel 4.2 : Jumlah Telur Nyamuk Berdasarkan Jenis Atraktan

\begin{tabular}{clcc}
\hline NO & JENIS ATRAKTAN & $\begin{array}{c}\text { JUMLAH TELUR } \\
\text { NYAMUK }\end{array}$ & $\%$ \\
\hline 1 & AIR RENDAMAN JERAMI & 1933 & 54 \\
2 & AIR RENDAMAN GULA & 402 & 11 \\
3 & AIR SETEMPAT & 1258 & 35 \\
\multicolumn{2}{c}{ TOTAL JUMLAH TELUR NYAMUK } & $\mathbf{3 5 9 3}$ & $\mathbf{1 0 0}$ \\
\hline
\end{tabular}

Jumlah telur nyamuk berdasarkan jenis atraktannya dapat dilihat pada grafik berikut ini:

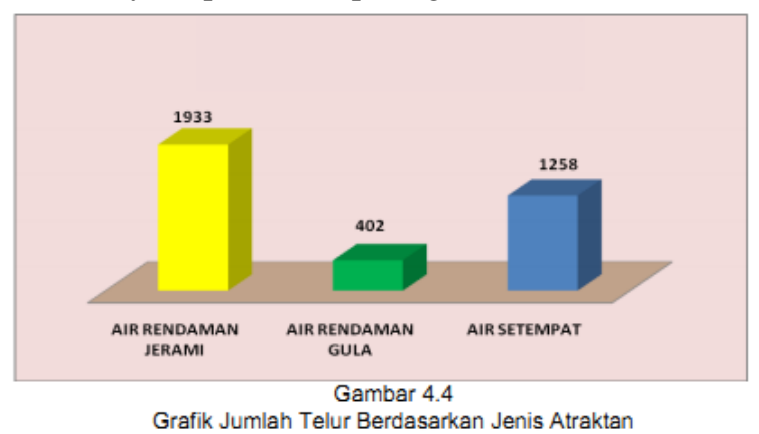

Jumlah telur nyamuk yang didasarkan jenis atraktan bervariasi. Jumlah telur nyamuk yang paling banyak pada jenis atraktan air rendaman jerami dengan jumlah 1.933 butir, jenis atraktan yang kedua yaitu air setempat dengan jumlah telur 1.258 butir sedangkan atraktan yang paling sedikit jumlah telurnya yaitu pada rendaman gula dengan jumlah 402 butir.

Nyamuk secara naluriah harus survival (mampu bertahan hidup), terhindar dari predator dan terdapat makanan yang membantu dalam kelangsungan hidupnya. Nyamuk mendapatkan makanan yang mengandung protein dari zat organik yang dapat diperoleh dari air rendaman jerami. Penyebaran jentik cenderung tidak merata di breeding site, tetapi cenderung bergantung pada tumbuhan air, flora dan plankton mikroskopis sebagai makanan jentik yang berada disekitar tanaman. (Aris Santjaka, 2013 h. 31)

Jerami secara tidak langsung menjadi sumber $\mathrm{N}$ dan $\mathrm{C}$ sebagai substrat untuk metabolisme biologi termasuk sintesis gula, pati, selulosa, hemiselulosa, pektin, lignin, lemak, dan protein. Jerami kering mengandung $40 \%$ C. Atraktan air rendaman jerami mengalami proses dekomposisi, karbohidrat terdekomposisi dan berat total dari jerami akan menurun. Kandungan nutrisi anorganik akan meningkat sejalan dengan peningkatan kematangan kompos. Volatilisasi nitrogen dalam bentuk NH3 mungkin dapat terjadi pada tingkat kebasaan sedang. Proses dekomposisi terjadi perubahan terhadap komposisi kimia bahan organik dari senyawa kompleks menjadi senyawa yang lebih sederhana. Dekomposisi bahan organik tersebut akan menyediakan unsur hara $\mathrm{N}, \mathrm{P}, \mathrm{S}$ dan unsur lain tergantung penyusun bahan organik tersebut. (Inoko, 1984 dalam Mudi Liani A, 2008)

Air rendaman jerami dapat dianggap sebagai atraktan oviposisi. Suatu zat dianggap sebagai atraktan dan stimulant oviposisi jika menyebabkan nyamuk betina gravid bergerak aktif menuju sumber zat tersebut dan terdorong untuk meletakkan telurnya di sana. Penelitian lain yang menggunakan alat olfactometer diketahui bahwa Ae. aegypti justru tidak tertarik terhadap komponen kimia volatile yang dilepaskan oleh rendaman jerami dan tertangkap indera nyamuk dari jauh. Senyawa volatil berasal dari dekomposisi zat organik yang terjadi dalam keadaan fakultatif maupun anaerobik oleh mikroorganisme. Peningkatan oviposisi Ae. aegypti diketahui berasal dari kandungan kimia non-volatil yang terkandung pada permukaan air rendaman jerami. Ketika tersentuh oleh organ sensory chemotactile nyamuk, kandungan kimia ini lebih merangsang nyamuk untuk bertelur, dibandingkan bau yang menarik nyamuk dari jauh. Kandungan kimia tersebut dimungkinkan berasal dari aktivitas mikroorganisme saat proses fermentasi berlangsung. Keatraktifan rendaman organik dipengaruhi oleh pertumbuhan bakteri pada rendaman yang juga meningkatkan produksi metabolit sekunder. (Milana Salim dan Tri Baskoro Tunggul Satoto, 2015)

$\mathrm{O}_{2}$, asam laktat, dan oktenol merupakan atraktan yang sangat baik bagi nyamuk. Aroma asam lemak yang dihasilkan dari flora normal kulit efektif pada jarak 7-30 meter, bahkan dapat 
mencapai 60 meter untuk beberapa spesies. Adanya $\mathrm{CO}_{2}$ yang terkandung pada air rendaman jerami, dianggap oleh nyamuk sebagai $\mathrm{CO}_{2}$ yang dihasilkan dari proses respirasi makhluk hidup karena nyamuk tertarik pada aktivitas makhluk hidup dengan cara mendeteksi keberadaan $\mathrm{CO}_{2}$ pada saat bernafas, radiasi tubuh dan bau keringat. Bagian tubuh host yang banyak mengandung darah akan menjadi sasaran empuk nyamuk untuk di hisap darahnya.

Air setempat yaitu sumur gali menjadi urutan kedua terhadap jumlah telur yang di dapatkan. Air sumur gali sebagai kontrol karena pada teorinya nyamuk Aedes sp menyukai air bersih untuk bertelur. Tempat perindukan nyamuk Aedes aegypti di genangan-genangan air yang tertampung disuatu wadah atau kontainer dan tidak pada genangangenangan air di tanah. Kebanyakan kontainer yang disukai nyamuk adalah yang berair dan berwarna gelap, terbuka, terlindung dari sinar matahari, dan umumnya ditemukan berada di dalam atau di luar rumah. Menurut Ditjen PP dan PL (2007c, h.5)

Gula lebih sedikit diminati nyamuk karena gula berjenis disakari mempunyai sifat mudah dicerna atau didegradasi oleh bakteri. Gula yang digunakan adalah gula pasir yang bewarna putih bersih, sehingga ada indikasi ada tambahan zat kimia yang membuat putih (gula rafinasi). Penambahan zat kimia tersebut menghambat disakarida menjadi monosakarida, sehingga $\mathrm{CO}_{2}$ yang dihasilkan berpengaruh dan nyamuk menjadi kurang tertarik pada atraktan gula yang dipasang.

\section{Jumlah Telur Didasarkan Pada Jenis Bahan Ovitrap}

Pemasangan ovitrap di RT 05 dan RT 09 RW 03

Kelurahan Teluk yang digunakan tiga jenis bahan ovitrap yang berbeda yaitu gelas plastik, kaleng, dan tempurung kelapa. Hasilnya dapat dilihat pada tabel berikut ini:

\begin{tabular}{lcc} 
Tabel 4.3 : Jumlah Telur Nyamuk Berdasarkan Jenis Bahan Ovitrap \\
\hline JENIS BAHAN OVITRAP & $\begin{array}{c}\text { JUMLAH TELUR } \\
\text { NYAMUK }\end{array}$ & $\%$ \\
\hline TEMPURUNG & 1326 & 37 \\
KALENG & 831 & 23 \\
GELAS PLASTIK & 1436 & 40 \\
JUMLAH TELUR NYAMUK & 3593 & 100 \\
\hline
\end{tabular}

Hasil jumlah telur nyamuk berdasarkan jenis atraktannya dapat dilihat pada grafik berikut ini:

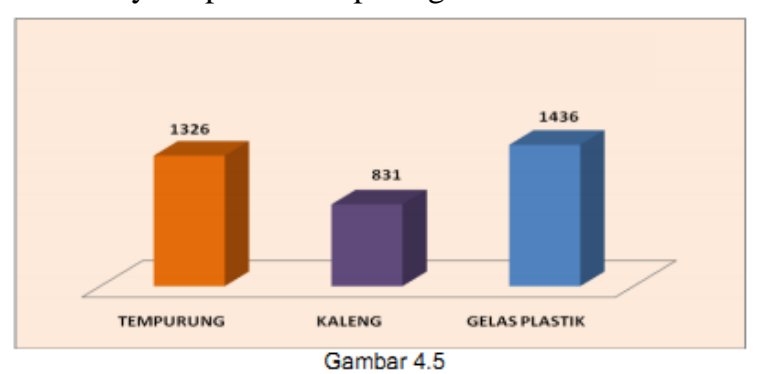

Grafik Jumlah Telur Nvamuk Berdasarkan Jenis Bahan Ovitrap

Jumlah telur nyamuk yang paling banyak pada jenis bahan ovitrap gelas plastik 40\% lebih tinggi dibandingkan dengan bahan ovitrap kaleng 23\% dan tempurung 37\%.

Jenis bahan ovitrap yang paling banyak ditemukan telur nyamuk adalah gelas plastik yang berisi atraktan air rendaman jerami. Hasil tersebut ada kemungkinan air rendaman jerami yang berpengaruh menarik nyamuk bukan karena jenis bahan ovitrap gelas plastik. Tempurung yang merupakan bahan ovitrap alami tetap berpengaruh terhadap jumlah telur yang didapat, ini terbukti pada air setempat yang tidak ada pengaruh tambahan sehingga netral, tempurung paling tinggi jumlah telurnya. Tempurung yang memiliki permukaan yang kasar menjadi bahan ovitrap alami yang disukai nyamuk

\section{Jumlah Telur Dibedakan Menurut Hari Penangkapan}

Pemasangan ovitrap dilakukan selama 2 minggu dengan pertimbangan minggu pertama pemasangan dilakukan selama 7 hari dengan pertimbangan siklus hidup nyamuk dari telur sampai ke fase jentik membutuhkan waktu 7 hari, sehingga pengamatan ovitrap dan pengukuran lingkungan fisik dilakukan pada hari pertama dan ketujuh. Minggu kedua dilakukan pengamatan ovitrap dan pengukuran lingkungan fisik setiap hari selama 1 minggu dengan tujuan untuk mengetahui perkembangan harian nyamuk untuk bertelur.

Terjadi kecenderungan jumlah telur yang didapat naik sampai hari ke 14 dengan rata-rata jumlah telur selama 7 hari yaitu 366 butir. Jumlah telur maximum (tertinggi) 1.273 butir dan jumlah telur minimum (terendah) 0 butir, sebagaimana dapat dilihat pada gambar 4.6.

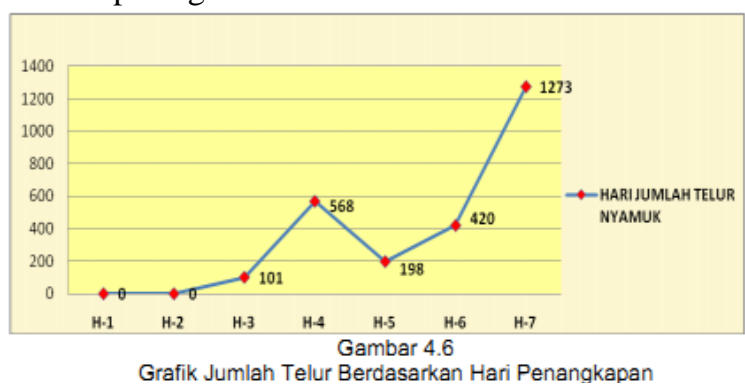

Jumlah telur nyamuk meningkat setiap harinya dan puncak tertinggi yaitu pada hari ketujuh dengan jumlah telur 1.273 butir. Nyamuk mulai meletakkan telurnya pada hari ketiga dan terus meningkat sampai hari ketujuh. Hal ini terjadi karena asumsi atraktan yang dipasang mengalami proses dekomposisi dan mengalami puncak setelah 7 hari penggunaan sehingga nyamuk lebih tertarik untuk meletakkan telurnya pada hari ketujuh. Kepadatan nyamuk dewasa dan kondisi lingkungan fisik sekitar yang mendukung, seperti suhu, kelembaban dan pencahayaan.

\section{Spesies Nyamuk Hasil Rearing}


Rearing yaitu mengembangbiakan nyamuk dari fase telur sampai dewasa, namun pada penelitian ini rearing dilakukan hanya sampai larva instar 3-4. Rearing nyamuk dilakukan di rumah peneliti sampai telur berubah menjadi larva intar 3-4. Penetasan telur dilakukan dengan cara memasukan ovistrip yang berisi telur nyamuk ke dalam container yang telah berisi air bersih dan container tersebut diberi kode asal telur didapatkan.

Spesies nyamuk dari hasil penangkapan telur menggunakan ovitrap dapat di identifikasi setelah larva menjadi instar 3-4, kemudian larva nyamuk di bawa ke laboraturium Kampus 7 untuk diidentifikasi. Hasil identifikasi spesies nyamuk yang didapat adalah sebagai berikut:

\begin{tabular}{|c|c|c|c|c|c|c|c|}
\hline \multirow[b]{2}{*}{ No Jenis Atraktar } & \multirow{2}{*}{$\begin{array}{c}\Sigma \\
\text { Telur } \\
\text { Nyamuk }\end{array}$} & \multirow{2}{*}{$\begin{array}{c}\text { E Jentik } \\
\text { Nyamuk } \\
\text { Yang di } \\
\text { Identifikasi }\end{array}$} & \multicolumn{4}{|c|}{ Jenis Nyamuk Aedes } & \multirow[b]{2}{*}{ KETERANGAN } \\
\hline & & & $\begin{array}{c}A \theta . \\
\text { aegypti }\end{array}$ & $\%$ & $\begin{array}{c}A \theta . \\
\text { albopictus }\end{array}$ & $\%$ & \\
\hline $\begin{array}{l}\text { Air Redaman } \\
\text { Jerami }\end{array}$ & 1933 & 41 & 33 & 80 & 8 & 20 & $\begin{array}{l}\text { Tidak semua telur } \\
\text { dapat menetas. }\end{array}$ \\
\hline $\begin{array}{l}2 \text { Air Rendaman } \\
\text { Gula }\end{array}$ & 402 & 0 & 0 & 0 & 0 & 0 & $\begin{array}{l}\text { Telur nyamuk tidak } \\
\text { menetas. }\end{array}$ \\
\hline 3 Air Setempat & 1258 & 31 & 21 & 68 & 10 & 32 & $\begin{array}{l}\text { Tidak semua telur } \\
\text { dapat menetas. }\end{array}$ \\
\hline
\end{tabular}

Hasil rearing tersebut dapat diketahui jenis nyamuk yang diperoleh pada rendaman jerami dan air setempat yaitu Aedes aegypti dan Aedes albopictus. Jumlah spesies yang paling banyak yaitu Aedes aegypti. Terdapat beberapa kendala pada saat rearing seperti tidak semua telur yang diperoleh pada ovistrip menetas semua, pada atraktan air rendaman gula tidak ada telur yang dapat menetas.

Rearing nyamuk dilakukan di rumah peneliti sampai telur berubah menjadi larva intar 3-4. Peletakan container berada di bawah genteng yang transparan sehingga sinar matahari dapat masuk keruangan dan mempercepat proses rearing. Hal ini terbukti rearing dari tahap telur sampai instar 3-4 hanya membutuhkan waktu 3-4 hari, sedangkan menurut teori butuh waktu 7-8 hari telur dapat berkembang menjadi larva instar 4 . Sinar matahari ini membantu pada proses moulting (berganti kulit), sehingga mempercepat proses rearing.

\section{Hasil Analisis Statistik Anova Faktorial}

Analisis statistik pada penilitian ini menggunakan uji ANOVA Faktorial yang bertujuan untuk mengetahui ada tidaknya perbedaan jumlah telur nyamuk yang terperangkap pada ovistrip di setiap jenis atraktan dan jenis bahan ovitrap. Hasil analisis tersebut adalah sebagai berikut:

Tabel 4.5 : Hasil Analisis Menggunakan Anova Faktorial

\begin{tabular}{ccccl}
\hline No & Variabel & $\mathrm{Fn}$ & $\mathrm{p}$ & \multicolumn{1}{c}{ Kesimpulan } \\
\hline 1 Jenis Atraktan & 9,716 & 0,000 & $\begin{array}{l}\text { Ho ditolak } \\
\text { (Ada perbedaan) }\end{array}$ \\
2 Jenis Bahan Ovitrap & 1,714 & 0,187 & $\begin{array}{l}\text { Ho diterima } \\
\text { (Tidak ada perbedaan) }\end{array}$ \\
$\begin{array}{l}\text { Interaksi jenis } \\
\text { atraktan dan jenis } \\
\text { bahan ovitrap }\end{array}$ & 1,718 & 0,155 & $\begin{array}{l}\text { Ho diterima } \\
\text { (Tidak ada perbedaan) }\end{array}$ \\
\hline
\end{tabular}

Hasil tersebut dapat diketahui bahwa:

1. Jenis atraktan nilai signifikannya 0,00 (p) $<0,05$ $(\alpha)$, artinya Ho ditolak pada jenis atraktan sehingga ada perbedaan jumlah telur Aedes sp yang terperangkap pada masing-masing jenis atraktan yang digunakan (air rendaman jerami, air rendaman gula dan air setempat).

2. Jenis bahan ovitrap nilai signifikannya 0,187 (p) $>0,05(\alpha)$, artinya Ho diterima pada jenis bahan ovitrap, sehingga tidak ada perbedaan antara jumlah telur nyamuk dengan jenis bahan yang digunakan (tempurung, gelas platik dan kaleng).

3. Interaksi jenis atraktan dan jenis bahan ovitrap nilai signifikannya yaitu $0,155(\mathrm{p})>0,05(\alpha)$, artinya Ho diterima sehingga tidak ada perbedaan interaksi antara jenis atraktan dan jenis bahan ovitrap.

Hasil analisis statistik diketahui bahwa untuk jenis atraktan Ho ditolak, dilakukan uji lanjutan.

Tabel 4.6 Hasil Analisis Lanjutan

\begin{tabular}{|c|c|c|c|c|c|}
\hline No & Jenis Atraktan & $\begin{array}{l}\text { Dibandingkan } \\
\text { Jenis Atraktan }\end{array}$ & $\begin{array}{c}\text { Mean } \\
\text { Difference } \\
\text { (MD) }\end{array}$ & Sig & Kesimpulan \\
\hline \multirow[t]{2}{*}{1} & \multirow[t]{2}{*}{$\begin{array}{l}\text { Air Rendaman } \\
\text { Jerami }\end{array}$} & $\begin{array}{l}\text { Air Rendaman } \\
\text { Gula }\end{array}$ & 56.704 & 0.000 & \multirow{3}{*}{$\begin{array}{l}\text { Ho ditolak } \\
\text { (ada perbedaan) } \\
\text { Ho diterima } \\
\text { (tidak ada perbedaan) } \\
\text { Ho ditolak }\end{array}$} \\
\hline & & Air Setempat & 25.000 & 0.056 & \\
\hline \multirow[t]{2}{*}{2} & \multirow[t]{2}{*}{$\begin{array}{l}\text { Air Rendaman } \\
\text { Gula }\end{array}$} & $\begin{array}{l}\text { Air Rendaman } \\
\text { Jerami }\end{array}$ & .56 .704 & 0.000 & \\
\hline & & Air Setempat & -31.704 & 0.016 & $\begin{array}{l}\text { Ho ditolak } \\
\text { (ada perbedaan) }\end{array}$ \\
\hline \multirow[t]{2}{*}{3} & \multirow[t]{2}{*}{ Air Setempat } & $\begin{array}{l}\text { Air Rendaman } \\
\text { Jerami }\end{array}$ & -25.000 & 0.056 & $\begin{array}{l}\text { Ho diterima } \\
\text { (tidak ada perbedaan) }\end{array}$ \\
\hline & & $\begin{array}{l}\text { Air Rendaman } \\
\text { Gula }\end{array}$ & 31.704 & 0.016 & $\begin{array}{l}\text { Ho ditolak } \\
\text { (ada perbedaan) }\end{array}$ \\
\hline
\end{tabular}

Hasil tersebut dapat diketahui bahwa:

1. Air rendaman jerami dengan air rendaman gula ada perbedaan karena nilai signifikannya $0,000<0,05(\alpha)$, sedangkan air rendaman jerami dengan air setempat tidak ada perbedaan karena nilai signifikannya $0,056>0,05(\alpha)$.

2. Air rendaman gula dengan air rendaman jerami ada perbedaan karena nilai signifikannya $0,000<0,05(\alpha)$, air rendaman gula dengan air setempat juga ada perbedaan karena nilai signifikannya $0,016<0,05(\alpha)$.

3. Air setempat dengan air rendaman jerami tidak ada perbedaan karena nilai signifikannya $0,056>0,05(\alpha)$, sedangkan air setempat dengan air gula ada perbedaan nilai signifikannya $0,016<0,05(\alpha)$.

Jumlah telur nyamuk yang didapat terbanyak pada jenis atraktan air rendaman jerami dan jenis bahan ovitrap gelas plastik. Hasil jumlah telur nyamuk berdasarkan jenis atraktan dan bahan ovitrap dapat dilihat pada grafik berikut:

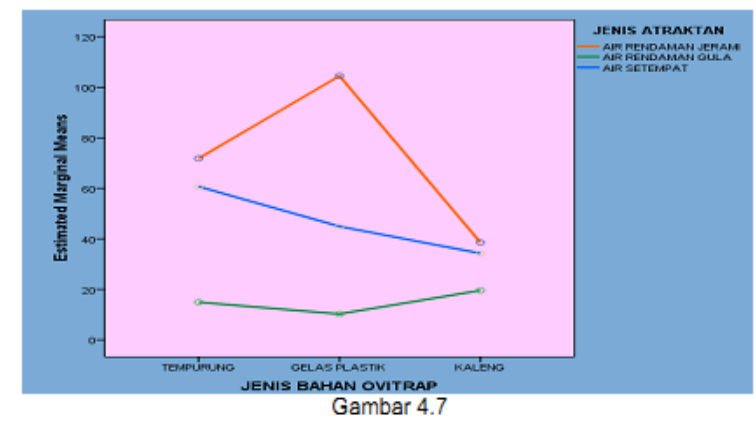

Grafik Jumlah Telur Nyamuk Berdasarkan Jenis Atraktan Dan Bahan Ovitrap 


\section{Hasil Efek Samping Penelitian Kaitan Dengan Literatur}

1. Telur lalat

Efek samping pada saat penelitian dilakukan yaitu adanya telur lalat yang menempel di ovistrip air jerami dan air gula. Telur lalat tersebut ada yang sudah berubah menjadi larva lalat. Bau yang ditimbulkan dari jenis atraktan tersebut cukup menyengat sehingga menarik binatang lain untuk meletakkan telurnya seperti lalat.

2. Ovitrap tumpah

Ovitrap pada penelitian ini diletakkan di dalam rumah, sehingga riskan tumpah karena tersenggol atau tertendang oleh anak-anak. Hambatan jalannya penelitian yang telah dilakukan yaitu ada dua ovitrap yang tersenggol anak-anak yang sedang bermain di dalam rumah, sehingga ovitrap yang berisi atraktan tumpah.

3. Banyaknya semut pada air rendaman gula

Atraktan air rendaman gula dapat mengundang serangga seperti semut, walaupun upaya untuk mencegahnya sudah dilakukan seperti menggunakan kapur semut di sekitar ovitrap dan penggungaan wadah tambahan yang berisi air pada ovitrap, namun semut tetap saja ada di ovitrap pada beberapa ovitrap rendaman gula yang dipasang.

4. Keterbatasan penelitian

Keterbatasan literatur menjadi hambatan pada penelitian ini, karena banyak hal yang baru sehingga belum dapat dijabarkan secara detail. Contohnya adalah sebagai berikut:

a. Secara teoritis siklus hidup nyamuk dari telur sampai larva instar 3 membutuhkan waktu 5-6 hari, namun dalam penelitian ini ditemukan ternyata tidak semua telur menetas, ada dalam waktu 3 hari sudah menjadi larva instar 3, dan ada yang 8 hari baru menjadi larva instar 3 .

b. Cara peletakkan telur nyamuk berbeda pada bahan ovitrap tempurung, telur nyamuknya lebih berantakan pada ovistrip dibanding pada bahan kaleng dan gelas plastik peletakkan telur lebih rapi dan mengelompok.

\section{KESIMPULAN}

Kondisi lingkungan fisik di dekat pemasangan ovitrap yaitu kelembaban dilokasi penelitian cenderung tinggi yaitu $77-90 \%$, pencahayaan di tempat peletakan ovitrap cenderung rendah yaitu 827 lux, dan suhu di lokasi penelitian cenderung tinggi yaitu 26-31 ${ }^{0} \mathrm{C}$. Jumlah telur Aedes sp yang terperangkap berdasarkan jenis atraktan yang paling tinggi pada jenis atraktan air rendaman jerami (54\%) dibanding air rendaman gula (11\%) dan air setempat (35\%). Jumlah telur Aedes sp yang terperangkap berdasarkan bahan ovitrap yang paling tinggi pada jenis bahan ovitrap gelas plastik (40\%) dibanding tempurung (37\%) dan kaleng (23\%). Hasil analisis uji statistik yaitu ada perbedaan jumlah telur Aedes $s p$ yang terperangkap pada masing-masing jenis atraktan yang digunakan (air rendaman jerami, air rendaman gula dan air setempat) dan tidak ada perbedaan antara jumlah telur nyamuk dengan jenis bahan yang digunakan (tempurung, gelas plastik dan kaleng) dan tidak ada perbedaan dari interaksi jenis atraktan dan jenis bahan ovitrap.

Hasil penelitian ini dapat sebagai masukan bagi::

1. Dinas Kesehatan Kabupaten Banyumas dan jajarannya untuk melakukan gerakan Pemberantasan Sarang Nyamuk (PSN) melalui gerakan $3 \mathrm{M}$ plus dapat diterapkan secara terpadu dan berkelanjutan dengan ditambah upaya pemasangan ovitrap dengan air rendaman jerami 20\% yang direndam selama 4-5 hari, berdasarkan uji laboraturium yang telah dilakukan pada hari tersebut air rendaman jerami telah menimbulkan bau yang khas dan jenis bahan ovitrap gelas plastik yang di cat hitam.

2. Masyarakat untuk dialukan pemasangan ovitrap gelas plastik dengan atraktan air rendaman jerami $20 \%$ dapat diaplikasikan dengan cara memasang ovitrap disekitar rumah dan setelah mendapatkan telur pada ovistrip, dapat dilakukan pengendalian telur dengan cara dijemur di bawah sinar matahari atau dapat di rebus dengan air mendidih, maka telur akan rusak dan tidak menetas.Pemasangan ovitrap dapat dilakukan serentak pada wilayah endemis dan digabung dengan kegiatan PSN DBD di setiap minggu,

3. Bagi Peneliti dapat dilakukan pengkayaan ilmu dapat dilakukan penelitian lanjutan dengan membahas cohort seleksi alam pertumbuhan larva pada air rendaman jerami dan air setempat.

\section{DAFTAR PUSTAKA}

Abdul Syukur, (2012), Analisis Spasial Faktor Risiko Lingkungan Terhadap Kejadian Demam Berdarah Dengue (DBD) Di Kabupaten Sambas Propinsi Kalimantan Barat, http://eprints.undip.ac.id/42537/3/03BABII abdulsyukur.pdf diakses tanggal 19 juli 2016 pukul 10.30 WIB

Arif Widyanto, dkk, (2015), Pengaruh Berbagai Jenis Atraktan Dalam Ovitrap Terhadap Jumlah Telur Nyamuk Aedes sp, Purwokerto: Politeknik Kesehatan Kemenkes Semarang Jurusan Kesehatan Lingkungan. 
Aris Santjaka, (2013), Malaria Pendekatan Model Kausalitas, Yogyakarta: Nuha Medika

Aris Santjaka, (2011), Statistik untuk Penelitian Kesehatan 2, Yogyakarta: Nuha Medika

Bento J dkk. (2003), Resistance of Aedes aegypti to organophospate in Several Municipalities in The State of Rio de Janeiro and Espirito Santo Brazil, American tropic Medicine Hygiene, http://repository.unhas.ac.id/.../JURNAL\%2 OYULCE.docx diakses tanggal 30 Desember 2015 pukul 10.00 WIB.

Borror, D.J. and Delong M, (1970), An Introduction To The Study of Insect, Holt, Rine Hart and Winston, New York. at http://pustaka.unpad.ac.id/wpcontent/uploads/ 2009/06/demam_berdarah_dengue.pdf diakses tanggal 29 Desember 2015 pukul 19.00 WIB.

Cecep Dani Sucipto, (2011), Vektor Penyakit Tropis, Yogyakarta: Gosyen Publishing

Chasan Sudjain Kusnadi. (2006). Pengendalian Vektor Dan Binatang Pengganggu, Makassar at http://dokumen.tips/documents/pengendalian-vektor.html diakses tanggal 2 Januari 2016 pukul 09.00 WIB

Dantji T. Sembel, (2009), Entomologi Kedokteran, Yogyakarta : CV ANDI OFFSET

Depkes RI, (1995), Menuju Desa Bebas Demam Berdarah Dengue, Jakarta: Dirjen PPM \& PL.

, (2009), Rencana Pembangunan Jangka Panjang Bidang Kesehatan, Jakarta : Departemen Kesehatan RI

Depkes RI Dirjen PPM \& PL, (2004), Profil Pemberantasan Penyakit Menular dan Penyehatan Lingkungan (PPM \& PL). Jakarta: Depkes RI Dirjen PPM \& PL

Departemen Kesehatan R.I. Direktorat Jenderal Pengendalian Penyakit dan Penyehatan Lingkungan (DIR.JEN.PP\&PL), (2007a), Ekologi dan Aspek Perilaku Vektor, Jakarta: DIR.JEN. PP \& PL

, (2007b), Pemberantasan Sarang Nyamuk Demam Berdarah Dengue (PSN DBD) oleh Jumantik, Jakarta: DIR.JEN. PP \& PL (2007c), Survai Entomologi Demam Berdarah Dengue, Jakarta: DIR.JEN. PP $\& P L$

Devi Nuraini Santi,(2001), Manajemen Pengendalian Lalat, Jurnal Kesehatan Lingkungan Vol. 1, No. 2, 2001, at www.usu.ac.id/lppm diakses tanggal 12 Juni 2016.

Dinas Kesehatan Kabupaten Banyumas, (2015), Laporan Kasus Demam Berdarah Dengue Tahun 2015, Purwokerto: Dinas Kesehatan Kabupaten Banyumas

Dinkes Sulsel, 2011, Waspada Demam Berdarah. At http://penanggulangankrisis.depkes. go.id/ article/view/6/1700/WASPADA-DE MAM-BERDAR.htm.diakses tanggal 6 Januari 2016 pukul 19.30 WIB

Dirjen PPM dan PLP, (1992), Petunjuk Teknis Pemberantasan Nyamuk Penular Penyakit Demam Berdarah Dengue, Jakarta: Depkes $R I$

Endang Puji Astuti, Roy Nusa R., (2011), Efektifitas Alat Perangkap (Trapping) Nyamuk Vektor Demam Berdarah Dengue dengan Fermentasi Gula, at http://ejournal.litbang.depkes.go.id/ index.php diakses tanggal 8 Januari 2016 pukul 20.30 WIB

Hadinegoro, Sri Rezeki., Satari, Hindra Irawan. (2004). "Demam Berdarah Dengue, Naskah Lengkap Pelatihan bagi Pelatih Dokter Spesialis Anak \& Dokter Spesialis Penyakit Dalam dalam Tatalaksana Kasus DBD”. Jakarta: FKUI.

http://satwa.net/1016/mengenal-nyamuk-aedes.html diakses tanggal 4 Januari 2016 pukul 11.35WIB

http://dinkes.lebakkab.go_.id-media-doc-postprosedur-pelaksanaanfogging\%20(1).pdf diakses tanggal 4 Januari 2016 pukul 11.00WIB

http://www.agrirafinasi.org/tentang-gula/rahasiagula/kwalitas-gula diakses tanggal 25 Juli 2016 pukul 22.00 WIB.

http://www.kompasiana.com/yuzahography/gularafinasi-vs-gula-kristal-putihk-kembar-tapidibedakan_55011a69a333117f73512bcd diakses tanggal 25 Juli 2016 pukul 22.30 WIB. 
Huan J., E.D Walker., J Vulule, and J.R Mille, (2006), Daily temperature profiles in andaround Western Kenyan larval habitats of Anopheles gambiaeas related to egg mortality Malaria Journal, at http://www.academia.

edu/7426929/pengaruh_suhu_terhadao_pe netasan_telur_nyamuk diakses tanggal 19 Juli 2016 pukul 10.00 WIB.

Jacquin, J. (2004). Insect Olfactory Receptors Contribution of Molecular Biology to Chemical Ecology. at http://eprints.undip.ac.id/42501/1/prosiding _IVM_komplit.pdf diakses pada tanggal 25 November 2015 pukul 19.00 WIB

Kelurahan Teluk, (2015), Profil Kelurahan Teluk Kecamatan Purwokerto Selatan 2015. Purwokerto: Kelurahan Teluk

Kementerian Kesehatan RI, (2012), Modul Pengendalian Demam Berdarah Dengue, Jakarta : DIT.JEN. PP \& PL

Milana Salim, Tri Baskoro Tunggul Satoto, 2015, Uji Efektifitas Atraktan pada Lethal Ovitrap terhadap Jumlah dan Daya Tetas Telur Nyamuk Aedes aegypti, Buletin Penelitian Kesehatan, Vol.43, No.3, September $2015 \quad$ : 147-154 http://ejournal.litbang.depkes.go.id/ index.php/BPK/article/view/4342 diakses tanggal 25 Juli 2016 pukul 0.33 WIB

Mudi Liani Amrah, (2008), Pengaruh Manajemen Jerami Terhadap Pertumbuhan Dan Produksi Padi Sawah (Oryza sativa L.), Bogor : Program Studi Agronomi Departemen Budidaya Pertanian Fakultas Pertanian Institut Pertanian Bogor.

Permenkes RI No. 374/MENKES/PER/III/2010 tentang pengendalian vektor

Primal Sudjana, (2010), Diagnosis Dini Penderita Demam Berdarah Dengue Dewasa, Jakarta : Buletin Jendela Epidemiologi Pusat Data dan Survailans Epidemiologi Kementerian Kesehatan RI Vol.2

Puskesmas Purwokerto Selatan, (2015), Laporan Kasus Demam Berdarah Dengue Dari Tahun 2010-2015, Purwokerto: Puskesmas Purwokerto Selatan

Rio Pamungkas, (2011), “Perbandingan Keefektifan Antara Ikan Cupang (Ctenops vittatus) Dan Ikan Nila (Oreochromis niloticus) Dalam Memakan jentik Nyamuk Aedes aegypti” ,
Semarang:UNNES,http:/JURNAL/-efektif antara-ikan.html diakses tanggal 9 Januari 2016 pukul 14.00 WIB

Ririh Yudhastuti, (2011), Pengendalian Vektor dan Rodent, Surabaya: Pustaka Melati

Sari, Cut, I, N, (2005), Pengaruh Lingkungan Terhadap Perkembangan Penyakit Malaria dan Demam Berdarah Dengue, at http://www.rudyct.com/PPS702-ipb/09145/ cut_irsanya_ns.pdf diakses 9 Oktober 2015 pukul 21.35 WIB

Sayono,( 2008), Pengaruh Modifikasi Ovitrap Dengan Kassa Nylon Penutup Permukaan Air dan Berbagai Jenis Antraktan Terhadap Jumlah Nyamuk Aedes Yang Terperangkap, Semarang at http://jurnal.unimus.ac.id diakses tanggal 4 Januari 2016 pukul 11.30 WIB

Sayono, dkk. (2010). Dampak Penggunaan Perangkap Dari Kaleng Bekas Terhadap Penurunan Populasi Nyamuk Aedes sp (Studi Awal Potensi Pengendalian Vektor Demam Berdarah Dengue Berbasis Komunitas), at http://jurnal.unimus.ac.id diakses tanggal 4 Januari 2016 pukul 11.00 WIB

Service MW,(1996),Medical Entomology for Students, London:Chapman \& Hall, p 54-78 https://core. ac.uk/download/files/379/11718326. diakses tanggal 10 Januari 2016 pukul 17.35 WIB

Singh, K. V. dan Bansal, S. K. (2005). Use of Different Ovitraps for the Surveillance and Control of Urban Mosquito Vectors, with Special Reference to Aedes aegypti. at http://www.icmr.nic.in/annual/200405/dmrc/ar45_1f.pdf. Diakses pada 10 Januari 2016 pukul 17.15 WIB

Soegeng Soegijanto,(2008),Demam Berdarah Dengue Edisi 2, Surabaya:Airlangga University Press.

Sofiyatul Mardiyah,(2014), Pengaruh Berbagai Konsentrasi Air Rendaman Jerami Sebagai Atraktan Terhadap Jumlah Telur Nyamuk Aedes aegypti Yang Terperangkap Di RW 04 Kelurahan Karangpucung Kecamatan Purwokerto Selatan Kabupaten Banyumas Tahun 2014, Purwokerto: Politeknik Kesehatan Kemenkes Semarang Jurusan Kesehatan Lingkungan. 
Supranto, J., (2000), Teknik Sampling untuk Survei dan Eksperimen, Jakarta: PT Rineka Cipta.

Supratman Sukowati, (2010), “Masalah Vektor Demam Berdarah Dengue (DBD) dan Pengendaliannya di Indonesia“ , Jakarta: Buletin Jendela Epidemiologi Pusat Data dan Survailans Epidemilogi Kementerian Kesehatan RI Vol.2

Taufiq Hidayat, (2007), Perbedaan Kesukaan Tempat Bertelur Aedes Spp Antara Ovitrap Tempurung Kelapa Dengan Gelas Kaca (Studi Lapangan Di Kota Purwokerto) Tahun 2007, at http://eprints.undip.ac.id/29103/ diakses tanggal 14 Desember 2015 pukul 18.30 WIB
Weinzierl, R., et al., (2005), Insect Attractants and Traps. University of Florida, at http://www.faunajournal.com/vol1Issue3/Is sue_mar_2014/3.1.pdf diakses tanggal 4 Januari 2016 pukul 11.30 WIB

WHO, (2007), Tren Dengue In Indonesia, Ganeva : World Health Organization

Widoyono, (2005), Epidemiologi, Penularan, Pencegahan dan Pemberantasan Penyakit Tropis, Jakarta : Erlangga.

Yulian Taviv, Akhmad Saikhu, Hotnia Sitorus, (2010), "Pengendalian DBD Melalui Pemanfaatan Pemantau Jentik dan Ikan Cupang di Kota Palembang”, Jakarta : Buletin Litbang Depkes Vol: 38, No.4 